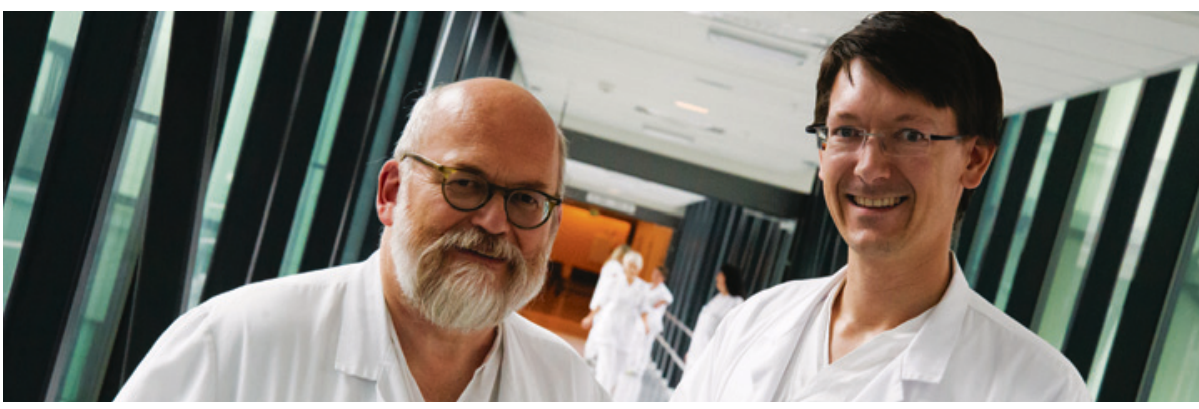

Dennis W.T. Nilsen og Øistein Rønneberg Mjelva. Foto Svein Lunde

MIN FøRSTE PUBLIKASJON

\section{Biomarkører ved brystsmerter}

\author{
Høye kalprotektin- og PAPP-A-nivåer er assosiert med dårlig prognose \\ hos pasienter med mistanke om akutt koronarsyndrom, men er ikke \\ selvstendige risikoindikatorer.
}

Pasienter med brystsmerter utgjør en stor andel av henvisningene til et akuttmottak. Slike pasienter må først få avklart om brystsmertene kommer fra hjertet eller ikke. Vanligste årsak til smerter fra hjertet er koronarsykdom, og en pasient med akutt koronarsyndrom trenger rask diagnostikk og behandling. Det kan være vanskelig å vurdere slike pasienter, og utredningen krever mye tid og ressurser. Gode biomarkører vil kunne forenkle den diagnostiske prosessen og sørge for at pasientene får riktig behandling raskere.

I en prospektiv oppfølgingsstudie har forskere i Stavanger undersøkt den prognostiske betydningen av de to potensielle markørene kalprotektin og svangerskapsrelatert plasmaprotein A (Pregnancy Associated Plasma Protein, PAPP-A) på vaskulær inflammasjon, plakkdestabilisering og plakkruptur og deres evne til å predikere risikoen for fremtidige dødsfall og nye kardiovaskulære hendelser (1). Studien omfattet 871 pasienter som ble henvist til akuttmottaket ved Stavanger universitetssjukehus pga. brystsmerter og mistanke om akutt koronarsyndrom i perioden 2002-03. Kalprotektin og PAPP-A ble målt i plasma ved inklusjon. Pasientene ble fulgt i sju år, og død, hjerteinfarkter og episoder med forhøyet troponin-T ble registrert.

- Vi fant at høye nivåer av PAPP-A var assosiert med signifikant økt mortalitet, sier Øistein Rønneberg Mjelva, som er førsteforfatter på artikkelen. Dette er hans første publikasjon. Også kalprotektinnivåer i den høyeste kvartilen sammenliknet med i den laveste kvartilen var assosiert med total dødelighet og predikerte det kombinerte endepunktet død eller nytt hjerteinfarkt. Etter å ha korrigert for mulige konfundere, var den prognostiske effekten av de to biomarkørene ikke lenger signifikant.

- Disse biomarkørene var altså assosiert med forverret klinisk utfall hos pasienter med brystsmerter og klinisk mistanke om akutt koronarsyndrom, men var ikke selvstendige risikoindikatorer. Markørene har vist lovende resultater i andre studier, men i denne studien ble deres prognostiske tyngde utvisket av kliniske variabler. Det trengs mer forskning på disse markørene før man kan si om de vil få en plass i fremtidens diagnostikk og prognosevurdering ved brystsmerter, sier Mjelva.

\section{Kardiologisk-biokjemisk forskergruppe}

Førsteforfatter Øistein Rønneberg Mjelva er lege i spesialisering ved Stavanger universitetssjukehus og er nå i en fireårig stipendiatstilling ved Universitetet i Bergen med sikte på en ph.d.-grad. Han er tilknyttet Kardiologisk-biokjemisk forskergruppe ledet av professor Dennis W.T. Nilsen. Denne gruppen er administrativt forankret i det kardiologiske forskningsmiljøet ved sykehuset og ved Universitetet i Bergen og samarbeider med andre forskere lokalt, nasjonalt og internasjonalt.

Gruppens interessefelt omfatter bl.a. testing av nye biomarkørers diagnostiske og prognostiske betydning ved akutt koronarsyndrom.

Mjelvas doktorgradsprosjekt har tittelen Cardiovascular biomarkers for prediction of outcome in coronary chest pain patients med Dennis Nilsen som hovedveileder, og gjennomføres i nært samarbeid med Trygve Brügger-Andersen, Volker Pönitz, Heidi Grundt og Ottar Nygård.

\section{Hanne Støre Valeur}

hanne.store.valeur@legeforeningen.no

Tidsskriftet

\section{Litteratur}

1. Mjelva OR, Brügger-Andersen T, Pönitz $V$ et al. Long-term prognostic utility of PAPP-A and calprotectin in suspected acute coronary syndrome. Scand Cardiovasc J 2013; 47: 88-97.
Ordforklaringer

Akutt koronar syndrom: Samlebegrep som innbefatter både ST-elevasjonsinfarkt, ikke-STelevasjonsinfarkt og ustabil angina pectoris.

Vaskulær inflammasjon: Betennelsesprosess i blodårer som man nå antar er av avgjørende patofysiologisk betydning for, og som leder frem til, det ustabile plakket i blodårene, som i neste omgang sprekker og danner grunnlag for okkluderende koronarsykdom.

Prognostisk biomarkør: Et molekyl eller substans som helst kan måles, og som opptrer som en indikator på en biologisk eller klinisk tilstand. Markøren sier noe om den fremtidige sykdomsutviklingen hos den aktuelle pasienten. 